\section{Formality and informality in an Indian urban waste economy}

Indian urban waste economy

Barbara Harriss-White

School of Interdisciplinary Area Studies, University of Oxford, Oxford, UK and Wolfson College, University of Oxford, Oxford, UK

\begin{abstract}
Purpose - The purpose of this paper is to contribute original evidence about the conditions for formal and informal contracts for commodities and labour in the waste economy of a South Indian town.

Design/methodology/approach - Field research was exploratory, based on snowball sampling and urban traversing. The analysis follows capital and labour in the sub-circuits of capital generating waste in production, distribution, consumption, the production of labour and the reproduction of society.

Findings - Regardless of legal regulation, which is selectively enforced, formal contracts are limited to active inspection regimes; direct transactions with or within the state; and long-distance transactions. Formal labour contracts are least incomplete for state employment, and for relatively scarce skilled labour in the private sector.

Research limitations/implications - The research design does not permit quantified generalisations.

Practical implications - Waste management technology evaluations neglect the social costs of displacing a large informal labour force.

Social implications - While slowly dissolving occupational barriers of untouchability, the waste economy is a low-status labour absorber of last resort, exit from which is extremely difficult.

Originality/value - The first systematic exploration of formal and informal contracts in an Indian small-town waste economy.
\end{abstract}

Keywords India, Informal economy, Business, Waste, Labour

Paper type Research paper

\section{Introduction: global and local in India's informal economy}

This special issue links the global with the local. If India's informal economy is defined as activity unregistered by the state, it is thought to be the largest in the world, consisting of about 60 per cent of GDP and no less than 83 per cent of all non-agricultural livelihoods (International Labour Office, 2012). That component of its competitive advantage makes India's informal economy of some global consequence; but the narrow alleys and gulleys of its towns and cities also have direct links with the global commodity economy through the production of an estimated 40 per cent of India's manufactured exports (National Council for Enterprises in the Unorganised Sector, 2008). India's informal economy is bound into the global service sector not just directly through the contractually vulnerable cyber-coolie labour force (Ramesh, 2004) but indirectly through the mass-multipliers of informal livelihoods servicing the booming IT sector (Harriss-White et al., 2013). It is through slumps in global demand for labour intensive products and services that the global financial crisis has affected India's informal economy (Harriss-White et al., 2013). But India's informal economy is also linked to global finance through unrecorded capital fleeing to offshore financial centres, some of which returns, laundered and readied for investment subsidies (Kar, 2010). Last, India's informal economy has been a testing ground for the global concepts in which it is framed. There is a large Indian literature tracing the concept's mutating

(C) Barbara Harriss-White. Published by Emerald Publishing Limited. This article is published under the Creative Commons Attribution (CC BY 4.0) licence. Anyone may reproduce, distribute, translate and create derivative works of this article (for both commercial \& non-commercial purposes), subject to full attribution to the original publication and authors. The full terms of this licence may be seen at http://creativecommons.org/licences/by/4.0/legalcode 
IJSSP

$37,7 / 8$

418

meanings and relating them to changing material conditions - or to changing understandings of them (see the reviews by Basile, 2013; Basile and Harriss-White, 2010; Chen, 2007; Kannan, 2008). Despite criticism of the crudity of the dichotomy (Raj and Sen, 2016), the concept has common currency and remains useful in identifying the limits of state intervention - both in principle or intention and in practice. The boundary between state and non-state regulation has been identified as "blurred" by the anthropologist Akhil Gupta (1995), while recently Aseem Prakash has rearticulated the "blurred boundary" as a political space (Prakash, 2014). We can ask what kinds of politics traverse this space and police the boundaries.

In trying to answer this question, my paper introduces a relatively neglected aspect of the informal economy: waste. Waste - material and substances without value (for, however, brief a time) - is produced by all human activity (Centre for Environment and Education (CEE), 2014; Dinler, 2014). India currently has one of the fastest-growing waste economies in the world, argued to be driven by its urban middle class, in which some waste regains value through recycling and re-use while social resources are devoted to the disposal of the significant residue. India as a whole generates $2.6 \mathrm{~m}$ tonnes of solid waste a day, of which 36 per cent is organic/agricultural waste, 30 per cent is industrial, 0.5 per cent is thought to be hazardous and the rest is from consumption (CEE, 2014, p. 4). Each day urban India discards roughly 250,000 tonnes of solid waste, approaching what the entire global urban population is estimated to have produced in 1900. India's "peak waste" - the point beyond which resource efficiency will drive a decline in absolute waste generation - is predicted to lie approximately a century into the future (Hoornweg et al., 2013). Meanwhile, the contribution of waste to the material balances of the economy is expected to do nothing but rise. Waste generation has been variously problematized as a problem of technology, management and planning; of land-use and the need for the permanent sequestration of spaces; of costs (and benefits) to the economy (CEE, 2014) (including the disposal costs of waste generated elsewhere: see the example of shipbreaking (Demaria, 2010)); of threats to public health, of poverty and oppressive, humiliating caste relations of ragpickers and scavengers (Gill, 2009; Human Rights Watch, 2014) and of aesthetics (Hodges, 2015).

This paper contributes to an empirical literature currently dominated by city research sites, a field examination of the local waste economy of a small, anonymous town of some 70,000 in South India (Harriss-White and Rodrigo, forthcoming). It explores the conditions of formal and informal contracts in a sector heavily regulated by the state. Not confined to labour arrangements, it also examines commodity transactions where relevant. Over and above the polar classes, Indian capitalism is distinctive in having generated an array of forms that combine both capital and labour on a continuum from "disguised wage work" (livelihoods that are apparently independent but in practice lacking in economic autonomy), through petty commodity production and trade (or self-employment - the commonest form of livelihood) to petty and intermediate capitalism (small family businesses, 95 per cent of which have a labour force of under 5, the all-India average being 2.4) (Harriss-White, 2012).

For reasons of tractability, however, the waste economy will be described through the heuristic device of the sub-circuits of capital and the processes of labour. It covers the structure, processes and formal-informal social relations of waste generated in production, distribution and consumption (which is how waste is generally made visible), in the production of human beings and labour, and in the day-to-day reproduction of society.

The empirical evidence results from interviews with 85 workers in the sub-circuits of the waste economy interviewed at first-hand in 2015 and 2016. Since much of the waste economy is unregistered and its totality is unknown to any single individual, qualitative exploratory fieldwork ventured from the formal municipal labour force into the informal economy of waste using a snowball sampling method plus early-morning traverses of the 
town, with a minimum of two respondents for each of the many livelihood niches discovered. Lawyers, activists, politicians and officials in positions of regulative power in local government were also interviewed - over a 100 respondents in all. Nonetheless, the material is presented as a qualitative analytical narrative, with an invitation to develop the exploration in future.

\section{The production of waste in commodity production}

Over and above greenhouse gases which are out of this paper's scope (White et al., 2012), factory production generates waste that is liquid, solid, biodegradable and non-biodegradable. The town generated case material of all types.

\section{Industrial alcohol}

On the edge of the town, a registered industrial alcohol factory[1] uses molasses[2], water and fossil-fuel energy to generate alcohol plus liquid waste, in principle non-toxic and biodegradable, in practice neither. Untreated molasses sludge is piped to a river bed from where evaporation solidifies the waste, and percolation contaminates the water table while unattended blockages and leaks further pollute the land and water nearby. Facing protracted, multi-level, critical, party-politicised campaigning, the factory was eventually forced by the local Pollution Control Board (PCB) to install a treatment plant converting waste into organic manure. In turn this created a by-product of waste dust which settled on, and irritated, plants and humans alike. The plant broke down and stopped work. Waste from this factory has negative social value and, unlike other processes inside the factory, is subject neither to records nor regular inspections.

Local ex-untouchable labourers (Dalits[3]) were evicted without compensation to provide the factory land. Under 10 per cent of the factory's labour force is registered and permanent - very few from the locality. Local Dalit workers are being "constantly sacked" from its casual labour force, have declined from 50 per cent 20 years ago to 12 per cent in 2015, are disproportionately concentrated in dealing with effluents and paid at an average of Rs 6,000 per month (one-third below the average for low-skilled labour and the 2015 unskilled Minimum Wage which are both Rs 9,000 per month). As a family wage these informal earnings are seriously inadequate[4].

The "heavy regulation" of industrial alcohol was described as involving a nexus of corrupt interest between the regulators, local politicians and the owners. Labour is also deliberately informalised both to contain costs and to express the owners' contempt for Dalits.

\section{Rice mills}

The 50 rice mills[5] ringing the town produce several kinds of solid waste: husk, bran, broken rice and ash - all theoretically biodegradable - all recycled, revalued as raw materials and sold through local wholesalers. Husk is used as fuel on site - and surplus is sold to factories with boilers from which burnt husk ash is abandoned on verges ("free for farmers" explained a miller, 2015). Bran generates edible oil, soap and paint in a solvent extraction process the waste from which is sold as cattle cake. Black and broken grains supply the intensive chicken industry. Bran sales alone are receipted as the solvent plant is accessible to the commercial taxes and food inspectorates.

In an industry undergoing massive concentration, expansion in capacity, capital intensity and logistical reach, it is only the small skilled labour force (of about 4 per mill) that is registered "and whenever we need a loan we're 'bonded'" (said a machine operator). While two to three Dalit women sweep the mill premises, waste work proper is one of the tasks for a migrant casual male labour force (numbering 10-15 per mill), paid in cash on a daily rate totalling Rs 6,000 per month. Most of this is remitted home leaving daily (food) allowances and discretionary perks to underwrite day-to-day existence.

Indian urban waste economy 
IJSSP

$37,7 / 8$

420

\section{Clothing accessories}

A clothing accessories industry[6] produces metal, plastic and cloth waste. Inside the factory, waste is marshalled alongside raw materials and equipment in a specialised supplies department. The stage of zero value is internalised. Factory waste is then sold as raw material to metropolitan re-processors with a paper trail of receipts marking its price.

The need for records explains the high proportion of the permanent labour here ( 25 per cent) while the factory average is 7 per cent. Of the total labour force of 810, 93 per cent are casual. Contact with waste metals and plastics is associated with a much higher proportion of Dalit casual labour (53 per cent) than in the machine rooms (5 per cent). Dalits are engaged in separation and aggregation and paid daily amounts totalling Rs 5-7,000 per month. In this case, permanent labour tracks transactions, while casual Dalit labour is used to contain costs.

While waste from industrial production is formalised in receipted transactions under conditions of long-distance exchange, capital intensive onward processing, and more or less selective regimes of state inspection, the handling and disposal of waste is physically heavy, low status and poorly paid work for labour that is unregistered, casual, and without any job security or rights - despite the constant need for it.

\section{Waste in systems of distribution}

Distributive activity is of two kinds. One is physical and logistical: our case is Indian Railways (IR)[7]. The second is economic, consisting of the marketing and circulation of commodities: the wholesale vegetable market was selected[8].

\section{Waste on Indian Railways}

"The problem of waste is cultural. Even educated people use the station as a dustbin" (IR Health Inspector). Railway transport generates solid and liquid waste as well as human waste, much of it combined at its spaces of generation - tracks (the territory of the engineering department which occasionally throws lime or bleach onto fouled ballast) and stations (the territory of the medical department). The latter has a wide brief, responsible for public health and disease prevention on railways as well as the health of the workforce, station cleanliness and the monitoring of water and food quality.

Recently, the control of station cleanliness was ordered to be subcontracted from direct management by IR to a private company - on terms generating a private rate of return on capital which may approach 33 per cent. Its labour force of 33 waste collectors (mostly women, mostly Dalit - with 14 in supervision and administration) is organised in shifts, and provided with uniforms, equipment and contracts. From public to registered private employment, wages have dropped by two-thirds to a daily rate of Rs 210 (Rs 5,500 per month - with less complete entitlements to occupational welfare than in the public sector). The deterioration in earnings requires an informal supplement and the working shift is stretched by extra hours spent separating (paper, plastic, card and glass), bagging and hauling station waste to sell, un-receipted, to wholesalers for an income supplement of about Rs 50 per day. Success in this self-employment will raise their total incomes to Rs 6-8,000 per month. Residual waste goes in two directions. First, as part of their unregistered work gatherers also screen and collect items from the "waste-waste" dumped in the station yards. Second, residues from this double screening are then regularly collected by a municipal truck crew and taken to the municipal dump-yard on the edge of town. There, another set of families informally screen it, prior to compacting by municipal JCBs and (illegal) firing. Meanwhile human waste from IR is supposed to be treated in a siltation tank but is in fact released into a ditch joining other wet waste from wedding halls, and thence to a foul marsh.

Here, there is a top-heavy super-structure of secure labour and a differentiated set of more or less formal wage and self-employment relations that are dominated by Dalit women. The structure of returns to formal labour is predicated on additional un-receipted earnings 
in the informal economy. And the formal-informal labour process generates the raw material for a further two tiers of socially stigmatised and - as shown later - severely pauperised waste hunter-gatherers.

\section{Wholesale and retail vegetable markets}

Meanwhile the town's vegetable markets generate uncontrollable quantities of edible and biodegradable waste. The town is a regional hub, dominated by an oligopoly of ten wholesale firms with licenced stores - expanding their reach nationally, experimenting with global exports and co-existing with over 400 retailers who rent flimsy stalls and who find accumulation much more difficult. The latter net about Rs 2-300 per day or Rs 6-7,000 per month. The preserve of backward caste men, Dalits and women are conspicuous by their absence.

Vegetable marketing generates waste in many ways:

(1) cuttings (from processing vegetables on site): stems, outer layers, leaves;

(2) perishables: tomatoes and brinjal are carefully harvested early in the day to avoid rotting. But damaged tomatoes or bruised carrots may not even be unloaded - the crates they are stacked in are worth more than a damaged load - so they are dumped on the edge of town;

(3) unloading hooks can also damage vegetables which quickly rot;

(4) white mushrooms discolour rapidly, cannot be sold and switch category to waste; and

(5) packaging also goes to waste.

But, though figures of 40 per cent waste have become commonplace (Food and Agriculture Organisation, n.d.) traders estimate that the proportion wasted in marketing is very unlikely to exceed 20 per cent, even for perishable vegetables.

Unable to cope, the municipality returns responsibility for vegetable waste to the market shopkeepers who supply it as a free good to the informal economy. Waste is recycled to commercial "white pig" farms, to rearers of black pigs and several big herds of cows. One wholesale dynasty has a portfolio containing multiple vegetable firms, transport businesses, a rabbit farm and cattle herds. Most vegetable waste, however, is raw material for the urban animal economy and is free, collected by petty producers and petty capitalists for stall-fed animals. The town is thought to have about 15 herds of six to eight adult cows. Meanwhile about 200-300 cows belonging to the poorest owners stray in bands of four to six throughout the town, running the lethal risk of eating plastic waste. The vegetable market also supplies free feed to 10-15 herds of urban goats and numberless chickens. Unused waste is packed onto lorries to be fly-tipped at the edge of town or delivered to the dump-yard.

With the exception of chicken, mutton and fish which have special marketplaces and weekdays, the slaughter of other animals (cows and pigs) takes place in the residential quarters where they are reared - and beef and pork are sold on makeshift stalls. Evidently, hundreds of unregistered or minimally registered, unregulated livelihoods (not all of which are low income) are generated directly and indirectly from the waste of the vegetable market alone. This workforce also shifts the types and sites of public health hazards from waste, dispersing it from marketplace nodes to alleys, domestic courtyards and compounds.

\section{Waste generated in consumption}

Throughout the settlement, all day but especially at night, waste is heaved from residential buildings onto common land, private vacant lots and verges - sometimes broadcast, sometimes strewn in the vicinity of municipal skips[9]. Apart from food waste, an entropic profusion of paper, plastic, polythene, card, glass, metals, cloth and consumer durables amasses: solid, non-biodegradable, re-usable and recyclable - or useless. To focus on the 
IJSSP

$37,7 / 8$

422

relation between formal and informal activity, this account of the consumption waste economy outlines four major types of livelihood: the formal municipal sanitation labour force[10], that of the private formally subcontracted company[11], the semi-registered wholesale hierarchy[12] and tribal waste collectors[13].

\section{Municipal sanitation work}

Domestic consumption waste, commercial waste and waste from public buildings are formally the remit of the municipality - the local state. But the mass of solid waste has grown by factors of eight to ten in the last quarter century, a rate incommensurate with that of Municipal resources. With little industry to tax, local government is penalised by a culture of fiscal non-compliance and is starved of revenue (see Jairaj and Harriss-White, 2006)[14]. Meanwhile the Municipal Sanitation Workforce (MSW) has declined by some 40 per cent, with no change in technology to increase productivity. The composition of waste has been revolutionised by the arrival of many kinds of plastic, by medical waste from private clinics and poorly biodegradable sanitary pads and nappies/diapers. Waste has spun out of municipal control and has required a vast increase in the army of unregistered workers who are encouraged to survive from engaging with it.

"We are machines" (female MSW). With 125 registered workers and 4 supervisors, the MSW has become severely understaffed. Official estimates of unfilled vacancies vary from " 60 " through " 80 women alone according to the rules" to "an actual need of 400 more" (female MSWs). The workforce reports to a Commissioner who delegates this responsibility to engineers "more concerned with roads and construction" (Jairaj and Harriss-White, 2006), themselves understaffed and unable to exert close vigilance or prevent the deterioration of urban public land into un-clearable dumping grounds.

Once a position reserved for Dalit women (Thorat et al., 2016), after manual scavenging was abolished in the 1990s[15], defecation work was de-reserved, its local government posts were effectively disinherited, the gender composition was passively masculinised through selective failures to replace female staff, and the MSW face constant attempts to replace them with casual labour on ad hoc contracts. Apart from drivers and helpers on trucks and tractor-trailers, the municipal workforce is formally organised in teams in which men collect "wet waste" and women sweep "dry waste" - though during the Monsoons the distinction vanishes in flooded urban alleys. After heaping, waste is heaved into tractor-trailers and at least 20 tonnes a day is taken to the municipal dump-yard. This place is no ordinary landfill in a remote valley or former quarry but consists of several acres on the southern edge of town confined by three to four metre-high corrugated-iron walls and literally full to bursting. Well over 1,000 tonnes is deposited there each month. Because by this stage the town's organic waste is mixed with non-biodegradable waste, the practice of composting in pits has stopped. While municipal supervisors have formal responsibility for the zoning and compressing of dump-yard waste, they informally organise its burning as well - thereby releasing toxic smoke into the atmosphere but enabling strata to be compressed for decomposition while cattle, pigs, goats and dogs forage on the smouldering surface.

The vast majority of municipal workers (70 per cent) are Dalits and Scheduled Tribes, a minority coming from backward castes. "No Muslim would do this work" (male MSW)[16].

All sanitation work is physically hard, smelly, disgusting and often dangerous: 90 per cent of municipal sanitation workers die before the retirement age of 58 , most from occupation-related health conditions (Human Rights Watch, 2014). Notwithstanding, this workforce is the "aristocracy" of waste labour. Men and women are paid equally at salaries three to four multiples of those without formal contracts (Rs 15-25,000 per month according to seniority of service) with rights to Employee State Insurance and medical treatment, with Provident Fund for retirement, half final salary pensions, weekend leave, 12 days' other leave per year, maternity leave and provision for work-related accidents and death. 
Unionised at 90 per cent, they are nonetheless unable to strike about injustices (lack of changing and washrooms, lack of uniforms, protective clothing and equipment which many have to purchase privately, unfair promotions) since the scarcity of municipal revenue is commonly known and this workforce is constantly confronted by the alternative forms of livelihood in consumption waste.

Even the formal "gold standard" contract is arbitrarily incomplete and full work rights are denied. For example, though entitled to outpatient hospital treatment, inpatient entitlements are denied to MSWs. Informal practices are permitted: the dump-yard fires are one such. Another is an arrangement at dawn when, after clocking-on but before the MSW embark on their routes, tribal Irular [17] are allowed to make the first of their several daily rounds, scavenging the town's streets. In a third instance, despite MSWs being forbidden to pick waste privately while they perform work for the municipality (a stricture collectively observed), women's official pay is supplemented by informal work cleaning private wedding halls while men will privately clean septic tanks. Technically unable to cope with present levels of waste production, this formal system sets the existence conditions for the informal economy of waste.

\section{Private subcontracting}

Acute revenue stress and practices of new public management have forced the municipality formally to subcontract one-third of the town to a private registered company, to which it transfers a much lower sum for the same services as it organises directly. The company's private business model combines technological upgrades (semi-automatic waste-compacting lorries and roadside skips capable of bulking and delivering 15-20 tonnes a day to the dumpyard) with a massive deterioration in labour conditions.

Families of labour, all Dalit and organised through an informal labour contractor, are effectively bonded for a period of three years, brought in long distances from another state, unable to communicate with local people, paid at the minimum wage without perks (earning a third to a quarter of the MSW salaries) and housed on common land in tent-like shacks. Naturally this already informal labour force supplements its exiguous income with "side-work" and its residential patch is piled high with white cement bags of segregated waste. Informal activity is hard-wired into the business model of municipal subcontracting.

\section{The waste wholesale hierarchy}

"There is money in waste" (wholesaler). In the informal economy of waste, after gathering and segregating, waste is sold to a dealer. The town has 15-20 dealers, not clustered as is usual in Indian towns (Stanley, 2015), but spaced evenly throughout the urban fabric to minimise the effort of transport, since so much waste is hauled on foot.

At this point consumption waste is re-commodified and gains value. Prices are formed outside the town. Dealers are price-takers for their own sales, deduct a minimum net mark-up and beat their purchase prices down. Large premiums from price differentiation reward waste collectors who segregate with precision. There are six common forms of paper, five grades of card, four types of plastic (whose purchase prices range from Rs 2 to Rs 18/kg); polythene is classified by micron (Rs 3-15/kg), glass bottles are bought in six grades for return to bottling factories, metals (and cables) are most valuable, varying from iron (Rs 20/kg) to copper (Rs 380). Each wholesaler aims to keep four to six suppliers "loyal" - effectively bonding them by loans, by the gift of gunny bags and cement sacks and by lending cycle-carts to suppliers. "Re-cyclists" have up to ten times greater productivity than those who collect and haul on foot, for not only can they transport heavier loads, they are also able to complete multiple rounds of their routes each day. Informal waste collectors/suppliers, mostly Dalit, earn between Rs 150-300 per day (Rs 4-8,000 per month). 
IJSSP

$37,7 / 8$

424

Wholesalers may sell with receipts, directly "on trust" at long distance to recycling and reprocessing firms with instant electronic bank transfers from the purchaser, or via itinerant agents who broker deals and advance payments. But at least half the town's "raw material" is delivered, un-receipted, along networks of caste, kinship and debt to an immense monopolist depot covering several acres of peri-urban land and managed by a multigeneration joint family of Nadars, a highly enterprising and upwardly mobile (toddy tapping) caste. "We are professionalising" (said a co-owner). Indeed their portfolio involves vertical integration and upgrading - extending to land for stocks, two metropolitan scrap yards and fleets of trucks and lorries.

From this firm comes the authoritative estimate that the informal urban work-force generates about 700 tonnes of recyclable waste and up to two million bottles each month.

With increasing scale and with management of the diversity of the value chains in which waste enters as raw materials come local monopoly returns. At this point a micro-precise sorting takes place for receipted sale at long-distance. "We deal in hundreds of categories" (co-owner). Aluminium vessels full of mother boards, wire, or plastic bangles, heaps of reinforcing rods, baled cardboard boxes and drifts of plastic flagons all await "export" for reprocessing. It is also at this stage that certain components re-enter newly developing second-hand markets, as commodities rather than raw material, e.g. auto components, hi-fi equipment and architectural/construction waste.

Informal transactions are selectively confined to labour and to relations of bribery and fraud with officials of the sales tax department and the police. According to a supplier, an "immense fortune" results from receipted, under-receipted and un-receipted transactions: this wholesale hierarchy also launders stolen goods. Harassment from the police and municipal officers, replaces physical hazards as the main risk in this part of the waste economy.

This scrap-yard employs a migrant workforce approaching 500 wage workers, imported for up to two years on verbal contracts from Hindi speaking states. Fed and housed in primitive conditions, women are paid under half the minimum wage (Rs 150/day or Rs 4,000 per month) and men slightly below (Rs 260/day or Rs 7,000 per month) without any further entitlements.

\section{Tribal collectors}

Although their work overlaps with that of others, Irular waste collectors, who may number 150-200, are distinguished here because they are distinguished by all the other elements of the workforce. "We never talk to them" (Dalit female MSW). "We have no contact with them" (scheduled tribe caste association official) "They are not really humans" (Female scavenger). "We are treated like animals" (self-employed Irular). Other scheduled tribal people called them "beggars" and "drunkards". Of the Irular, we were told "a dog is still a dog even if you bathe it".

While other waste workers also make bricks, knot garlands, clean wedding halls, fish in water holes and make several daily rounds of the waste-routes that are far from cleared by the official labour force (all gaining daily between Rs 50 and 300 (Rs 1,300 to 8,000 per month)), the Irular hold the informal monopoly over the final screening of consumption waste at the foetid dump-yard. Dump-yard territories are allocated between families in a way they describe as "amicable". "We are united" (Irular dump-yard worker). After the lengthy morning shifts, pickings are heaped and left over several days for classification and bagging without fear of theft. Then sorted waste is heaved onto cycle-carts and taken to a particular dealer, who, unlike other scrappers, gives clothing and food at times of festivals. Here they are discriminated against in price, receiving about half what other suppliers obtain for identical items: Irular waste work generates half the income of the similar work of other castes. Despite most also being bonded to this dealer by loans, sacks and cycle-carts, they report daily average incomes of about Rs 150-200 per day (Rs 4-6,000 per month). 
These incomes are in decline. An influx of temporary, destitute, migrant, waste workers coupled with the unofficial licence given to the privately subcontracted municipal labour to screen as they collect means that recyclable waste, itself expanding in volume, is being shared by ever larger numbers of people. The Irular have no social organisation above kinship through which to mobilise opposition to this encroachment onto their territories. So the economic roles of non-waste work, where they are in direct competition with higher status workers, become ever more important to their survival.

Consumption waste is disproportionately the economic territory of Dalits and tribal workers, naturalising the way they are stigmatised and discriminated against, in and outside work, justifying the exclusion of many from rights to even the minimal social security benefits accorded "untargeted" to the poor (Desai et al., 2010). Informal waste work is also the safety net for vagrant people disenfranchised from dependence upon others by cross-caste elopement, addictions, certain diseases, disability and crime. The lack of extortion meted out by local government officials and the police to "temporary-permanent" verge dwellers and their verge economy is a powerful indicator of the social importance of their work - despite their deep poverty and compromised citizenship[18].

\section{The production of labour and human waste}

The production of labour power involves the production of labour and this in turn involves human waste[19]. Despite the relatively early abolition of manual scavenging and the installation of septic tanks in Tamil Nadu - starting in the mid-1990s - none of the town's human waste is treated. Since much of the residential fabric is congested, and since the subsidies provided do not meet the total installation costs, only half the houses have septic tanks. But the positioning of septic tank waste ducts is explicitly encouraged by the municipality to syphon liquid and semi-solid human waste into open drains. From the remaining dwellings, human waste is tipped or deposited alongside the other kinds of consumption waste and animal manure in the inadequately and unreliably flushed drains and urban gulleys where pathogens such as rotavirus, campylobacter and human roundworm flourish (Coffey et al., 2015). From this distribution system, untreated human waste is deposited either alongside other waste or in river-bed pools so close to the town's drinking-water pumping-stations that the latter are being relocated. Only in the rainy seasons is human waste flushed away from the town's territory. The authoritative Human Rights Watch Report on Open Defecation corroborates the implications for livelihoods of the sorts of conditions of human waste found in this town:

"Urbanization has increased open defecation that needs to be cleaned. Where people used to go to the fields, they now defecate in the roads. The drains have to be cleaned" [...]. "(The) manual cleaning of open defecation from roads and other areas, remov(es) excrement flushed into uncovered drains by private households in rural, semi-urban, and underdeveloped urban areas, or manual cleaning of private and government septic tanks (persists)" (Human Rights Watch, 2014, p. 32, p. 14).

(P)eople are employed as manual scavengers to clear open defecation areas and pour-flush toilets in public places, to provide sanitation in hospitals and nursing homes, and to clean sewers, septic tanks, drains, and railway tracks (Human Rights Watch, 2014, p. 66).

But far from being stigmatised manual scavengers, their replacements are formally contracted municipal workers/sanitation workers with some of the rights of the civil service and a de-reserved job.

Although the municipality, the colleges, schools, hospitals and police stations commission private tanker businesses[20] to void their septic tanks of faecal sludge, these also operate in the informal economy. "They often require us to do it for free" (septic tanker owner). Owned by one Dalit and one scheduled tribal entrepreneur and operated by Dalit and tribal kinsmen, the town's two fleets of five tankers face low capacity

Indian urban waste economy 
IJSSP

$37,7 / 8$

426

utilisation and fickle returns to investment due to lack of demand. Property owners forget to void the tank or seek to evade the private costs of cleaning (Rs 1,200). "An average septic tank should be cleaned once every 3-5 years but here people tend to contact us once in a generation or in an emergency when their tank overflows" (septic tanker owner). Fleet owners are harassed and fines are extorted by the police for dumping the contents of septic tanks, untreated, in a local water body. "What's the alternative?" one owner asked.

Here formal waste-work is essential to the disposal of human waste in conditions which break many sanitation regulations. None the less, a small informal labour force structured by family and kin is strategically deployed in septic-tankering without which the town's public hygiene would be non-existent.

\section{The production of waste in the reproduction of society}

The biological reproduction of the urban population is part of a wider process of social reproduction across the classes and generations. Although it is agreed that gender relations and the family play a key role in both types of reproduction, there is no scholarly consensus about the other institutions indispensable to social reproduction. In most capitalist societies, over and above the production-distribution-consumption system described here, social reproduction requires basic utilities: electricity, water, communications; the provision of infrastructure for basic needs and capabilities: schools, colleges, tutoring and training institutes, clinics, hospitals and banks; and the provision of protection and legal order: the police and fire services, courts and defence - and the state's fiscal, developmental and regulative administration. Many of these conditions are provided by the state, some in a combination of state and private capital. All, even the infrastructure for waste disposal itself, produce waste. In this last empirical section, we select first the public and private provision of health care without which labour cannot be reproduced - biologically and socially[21] and second the alcohol ("liquor") industry[22].

The latter requires some explanation. Throughout India, alcohol suffers from a tension - and is vulnerable to accusations of political hypocrisy. On the one hand it is regarded as a social evil and to be dis-incentivised or prohibited. On the other it is a welcome source of revenue for cash-strapped states (Kim, 2008). Neither quite describes the ambivalent role of alcohol in the reproduction of the waste economy. On the one hand in being a necessary therapy before and after work (very few formal and informal workers of either sex being able to abstain here), it is an essential component of the reproduction of labour power. On the other hand it pauperises in several ways. As an essential item of expenditure it reduces the value of the wage, and incentivises informal "side-jobs", lengthening the necessary hours of the informal working day and reproducing the conditions it alleviates. "Alcohol is a regular expense for women and men because of the smell and maggots - many of us get addicted" (Male MSW). The ill-health that follows from addiction also reduces life expectation.

\section{The waste economy of healthcare}

The town is something of a health hub with a large public hospital, a dozen private hospitals endowed with wards only one of which has intensive care, plus several dozen smaller private clinics, many diagnostic labs, drugstores and non-allopathic health services.

Public healthcare waste:

Yes, we are called "dirt-dealers by patients" (PHFHK[23]).

In the public hospital, waste is highly organised. With nearly 300 "housekeepers" who clear waste inside the building, plus 15 supervisors plus sweepers for the outside grounds and over 50 security men who, inter alia, stop night-time fly-tipping, the hospital's sanitation 
labour force far exceeds the municipality's whose responsibility covers the entirety of urban public space.

Wards are known to housekeepers by their waste-generating capacities. Maternity is by far the most productive of waste ("the town produces 800 children per month" (medical doctor)) followed by fire and accident, casualty/intensive care and surgical theatre/medical wards. Since the burden varies greatly within the hospital, housekeepers are constantly shifted around. The work involves cleaning lavatories, separating and transporting ward waste to skips classified for general and food waste (green); bloody waste, wound and other dirty waste (red); "biomedical" waste (sharps, syringes, pills, etc.) (blue); and body parts, limbs and placentas, etc. (yellow). Though separated, the first two kinds of waste (some 10-20 tonnes per day) are taken in municipal trucks to the dump-yard. Blue-labelled biomedical waste (about $50 \mathrm{kgs}$ a day, details of which are carefully recorded) enters a separate "sealed" disposal system managed by a private oligopoly and intended to feed a distant incinerator. This has been closed by the PCB owing to its own toxic effluent gases and biomedical waste is currently buried in pits. Inadequate capacity and "leakages" fuel an informal economy of (infectious) plastic and metal biotrash (Hodges, 2013, 2015). "Some hospitals violate procedure and corpses are carried to the dump-yard in an open truck. The alcohol they provide to sanitation workers incentivises us to do this - it's the same with body parts, placentas, stillbirths and aborted foetuses" (female MSW). Urine and faeces are stored in a battery of septic tanks and voided regularly though informally by the private septic tanker service.

In total, 75 per cent of the workforce consists of women from Dalit and tribal castes, supplemented by a few Christian and backward caste workers. As with the municipality and IR, strained financial resources plus government orders to subcontract services have forced the hospital to lay off a previously unionised, formally registered, public sector labour force which was rehired un-unionised with private formal contracts. "We are under contract these days" despaired a PHMHK. Privatisation lowered average monthly wages from about Rs 12,000 to Rs 4,200 (after Rs 700 deductions). Male and female pay is equal. These are so far below living wages for families that they incentivise moonlighting and informal supplements. Yet, the long shifts are incompatible with other activity. The formal contract is also incomplete. While provident fund and employee state insurance are provided, there is no medical insurance - sick leave and holidays are taken without pay. While uniforms, gloves and masks are provided, there are no changing rooms and only rudimentary hand-washing facilities.

Inside the hospital the work is hard and long, heavy, smelly and nauseating. It also exposes the workforce to infection. Outside the hospital in public space, night-time security is so dangerous to female housekeepers that the night shift is male.

Private health care waste:

"Health is big business"[...] "My relatives ask me why I do such a filthy job, but this hospital is my 'parent-home'. I am proud of my reputation in the hospital and I am grateful to its owners". "This work is not compatible with family life" (PvHFHKs).

In two ways - through ownership and the labour force - private hospitals are linked to public ones. They are owned in meshed combinations of moonlighters from public hospitals and private partnerships with overlapping specialist portfolios and links to the insurance industry. Their workforces have been formally trained at public cost and may also be drawn from the pools of young trainee labour waiting for government jobs and of retired public health care workers unable to live on their pensions. There is no retirement age in private health care.

Social relations of waste in private hospitals are characterised by flexibility, discretion and patronage. Illiterate "housekeeping" labour cleans wards (and lavatories) and sorts waste but may also be asked to perform nursing and other paramedical tasks (dealing with 
IJSSP

$37,7 / 8$

drug bottles, "dressing wounds", "personal services", patients' faecal relief at dawn), clotheswashing services and medical equipment washing, theatre assistance and portering. Of medicines: "people have described the labels to me and now I know their contents". "I get used to the English instructions". "Nurses read me anything I can't understand" (PvHFHKs). Most private hospital housekeepers are Dalit, female, illiterate or poorly educated.

The contract is on the informal end of the formal-informal continuum. A typical wage is Rs 6,500 per month. "I have been on a verbal contract for 20 years" (PvHFHK). This verbal contract may entitle the housekeeper to free medical treatment (but subsidised for their family), subsidised private education fees for their children, festival bonuses and access to loans of up to a month's salary. The very long shifts (10-12 hours) and leave are also negotiable. Maternity leave is generally granted without pay but with assured return to work. Uniforms, masks and gloves are usually supplied but, as everywhere, sanitation for sanitation workers is conspicuously absent. "If no-one watches - we can sneak in to the labour ward staff toilets" (PvHFHK).

Waste may be classified differently from in the public health system in a detail that does not match the formally state-regulated one: "needles and sharps; syringes; blood transfusion and blood products; drug bottles; saline and glucose bottles; dirty cottons; plastic tumblers, paper; food waste" (PvHFHK). Housekeepers may even sell some waste privately into the informal wholesale hierarchy. But biomedical waste tends to be treated separately: "The collectors ask us for proper packaging so they do not have to touch it" (PvHMHK). Even so, both the Irular dump-yard workers and the MSWs testified to the dumping of hazardous biomedical wastes by some of the town's private hospitals/small clinics. And one PvH HK rapidly retracted a statement that some biomedical waste was burned in the hospital grounds.

Hospital waste is handled by workers hired under a great range of contractual forms and work rights revealing how the loyalty of labour and the discretion and patronage of employers replace state entitlements and regulation. But in this formal-informal continuum, it seems that the more dirty and dangerous the work, the lower the pay and the more physically taxing the work conditions.

\section{Alcohol and waste}

"Selling alcohol is such heavy work" (Liquor man). "Alcoholism is almost normal - such a horrible job handling stinking maggoty waste" (Male MSW). "My store produces 3,000 empty bottles a day" (Liquor man)[24].

The days of toddy tapping and arrack distilling are long gone - liquor is dominated by beer and brandy and is heavily state-regulated. Public and private breweries and distilleries supply a state retail monopoly ("Tasmark") where prices are fixed at rates that pour tribute into the public fisc. Two of the hundred employees of Tasmark's stores estimated that the town's liquor consumption has increased by a factor of about 30 in the decade from 2005 and that the social composition of drinkers has cosmopolitanised - extending from lawyers and policemen to construction, brick, timber, sex and waste workers.

Both men and women waste workers drink before and after work: "before" in psychological preparation; and "after" to mask the physical pain in their joints and muscles. Brandy is commonly purchased in quarter bottles[25] and thrown down the throat for an immediate "punch" with a slower pain-diffusing after-effect. An average waste-worker will earn the soubriquet "alcoholic" by spending Rs 90-150 per day on alcohol - often shared with a spouse, but reducing their joint income by approximately one-third. The free rice ration is thus a vital compensation in which the food subsidy and alcohol tax mutually complement each other. 
In this town, alcohol outlets generate about one million glass empties per month which enter the waste economy to be repatriated to their factory of origin, each type embossed with their trade-mark, each having well-known prices[26]. All types of waste worker will recycle glass bottles, gathering and classifying them, washing them if possible, prior to re-valuing them through sales to the wholesale scrapping hierarchy, or to specialised bottle-men with crates and vans. Nearby, four "chemical washeries" each employing about 40 Dalit women will then flush residues from bottles before launching them on another cycle.

The circuits of liquor also lock an informal and illegal commodity economy into the formal, legal one. For 12 hour shifts and seven day weeks the Tasmark salaries are extremely low: between Rs 3-5,000 per month plus basic benefits. But this job is so highly lucrative that many endure "formal casual" status indefinitely. Each bottle yields a legal Rs 5 commission which can increase the salary tenfold. Beside each shop is a bar, rented out at 2.5 per cent of its gross output. A typical rent will be Rs 180,000 per month. Out-of-hours drinking in the bar fuels a black market in which "quarter bottles", formally fixed at Rs 90, will fetch up to Rs 200. Black market rents will be added to salaries. Illegal wholesale purchases for village retail sales plus the adulteration of regulated alcohol with illegally supplied rectified spirit expand informal markets and incomes further.

The waste from alcohol consumption is dangerous. Broken bottles around retail liquor outlets are a hazard to any of the general public foolish enough to stray into these spaces. "At least two thousand bottles are thrown around the site of my shop daily. Most won't break. But broken glass is exacerbated by fights around bars" (liquor-man). At night broken glass is a hazard to prowling animals. By day most broken glass is collected by formal MSWs and informal waste gatherers, added to general waste and offloaded onto the dump-yard to be avoided by workers there: Irular gatherers and their children, MSWs and herdsmen.

While formal procedure is violated, the state-regulated liquor economy requires the informal economy of bottle-recycling for it to operate. Informal transactions are not simply the repository of poverty, they may generate lucrative livelihoods.

\section{Conclusions}

\section{Mainstreaming waste: what waste confirms about informality}

The case of waste confirms the vital economic importance of registered private firms in an economic sector formally dominated by institutions of the state. The largest local firms are formally registered intermediate capitalists employing family and wage labour on casual or verbal contracts. While registered and as a result able to establish and operate bank accounts, these firms flout the laws regulating labour, the environment and tax. Informal fines replace legal enforcement. Registered firms profit economically from the debt-tying of many waste-gatherers; they also profit politically from networked relations with the key departments of government: the municipality, commercial taxes and the police.

The great majority of livelihoods from waste consist of unregistered, informal, self-employed petty gatherers and traders. Their exchange relations, bound to commercial capital, are on terms that prevent their own assets - their tools and equipment - from expanding. The sector grows through the multiplication of many tiny "enterprises" rather than by the concentration and centralisation of capital. In a politics of ignorance and complicity, the state tolerates these livelihoods.

The wage labour force is starkly differentiated by work status. Formal municipal workers have fullest rights both in and out of work but these rights are nonetheless incomplete. Yet even unionised municipal workers are unable to strike to improve them. In privately owned companies, irrespective of whether they generate or dispose of waste, labour contracts are rarely other than verbal, discretionary, flexible and incomplete. Meanwhile the larger segment, casual labour, forms an informal precariat in the strict sense defined by Standing (2011): without rights at work and with few entitlements outside work. 
IJSSP

$37,7 / 8$

430

Informality is more a political process than a binary state existing in opposition to formality, a process in which laws incentivising business are more likely to be enforced whereas laws adding to its costs are flouted. Formal contracts and behaviour are incompletely state-regulated and politicised. To cast "formalisation", either of economic behaviour or of welfare, as a solution to informal activity is to ignore the deep penetration of informal practices into formal, state-regulated activity, traced in this empirical paper.

\section{Exceptionalising waste - how the case of waste advances understanding of informality}

In law, most of the stages of the waste economy, whether handling valueless material or engaged in its re-valuation, are heavily state regulated. In practice, the state's capacity to enforce the law is severely compromised. The "boundary" of state regulation is policed by the relation between the dispersed sites of waste generation and the state's lack of resources, lack of transport and other equipment needed for inspection and sanction, and lack of staff, together with strategic and selective collusion between its agencies and private business.

Commodity transactions are registered under limiting conditions: under active inspection regimes (most well-funded in the case of commercial taxes), when direct transactions with the state must be tracked; and for long-distance transactions in which zero value waste moves to positive value. Labour contracts are most likely to be written and "formal" when pertaining to state employment, despite the widespread shedding and casualization of permanent public-sector labour. Elsewhere, contracts are least incomplete when skilled and relatively scarce labour needs retaining. Both the state and the registered private sector deliberately connive to create and perpetuate informal activity wherever it reduces their costs or stabilises or increases profits (as e.g. in the municipality's toleration of verge-side shacks and tents and the accommodation by the formal labour force of dawn rounds of informal gathering, which reduce the burden and costs of clearing consumption waste).

Unlike other sectors of the informal economy there are no business associations to compensate institutionally for the absence of state regulation. Collective action is strikingly absent and regulative power is in the hands of individual purchasers of gathered waste. Contracts show considerable variation and discretion; disputes - and there are many - are brokered unsystematically by caste association officials, social movement volunteers or locally respected patrons. Work in the informal economy of waste is regulated through caste, ethnicity and gender - disproportionately low status and considerably female. Caste power is a dynamic social force. The low-caste-specificity of waste is being dissolved fastest among the state-regulated municipal labour force where Backward castes have entered the sector. Although the lowest caste Dalits and tribal Adivasis are found widely outside the waste economy and are not confined to it, in the informal waste economy very few livelihoods are other than for individuals with lowest social status. And once working in waste, it is next to impossible to exit and move to work with higher economic status and returns.

The role played by the state in the waste economy for which it is formally responsible is both differentiated and ambivalent. On the one hand, municipal sanitation workers, even from the lowest castes, have a social status derived from their "respectable" work for the state. In being the provider of food of last resort through the public distribution system, it is the state that rescues the poorest informal waste-gathering families from begging. On the other hand, the capture of power points in the bureaucracy and judiciary by upper castes de-secularises the state and imbues it with socially oppressive practices. Liberalisation has increased the pace of private subcontracting of public services. This on-going process has dealt severe shocks to the incomes of waste workers who are re-employed and more or less formally registered in private companies. They experience the informal supplementation of their working day and their takings as coercive. The latter approach the levels of informal self-employed workers and are far below poverty lines/minimum wages for families. 
The informal economy of waste generates a special perspective on informality. India's productive economy could not function without its waste-disposing economy. The latter in turn has two type of legal status. Its resource-deprived, formal, registered waste-disposing economy is utterly dependent on the informal economy of waste and its considerable workforce, a dependence that is underpinned and policed by a wide range of forms of social coercion. There is no sign of any improvements in the foreseeable future.

\section{Acknowledgement}

Fieldwork was funded by the ESRC-EU through the London School of Economics' project on Inequality and Poverty www.lse.ac.uk/anthropology/research/Inequality-and-Poverty/ Home.aspx. All views expressed here are personal. The author is grateful to Alpa Shah, the Project Director, and to the Funders, to Gilbert Rodrigo with whom the author carried out the field research on waste in 2015 and 2016, to the participants at the 2015 Sheffield Conference on "The Informal Economy: Global and Local" and to two anonymous reviewers.

\section{Notes}

1. Informants: two members of local government.

2. Waste from sugar cane crushing.

3. The term Dalit connotes oppression and ex-untouchability in circumstances where calling people by their ex-untouchable caste names is regarded as illegal under the Scheduled Caste and Scheduled Tribe (Prevention of Atrocities Act) of 1989 (amended in 2015). India-wide, in the latest published data for 2001, Scheduled Castes comprise 16.6 per cent of the population while Scheduled Tribes are 8.6 per cent.

4. In $2015-2016$ Rs 100 hovered around $£ 1$ sterling. A month is taken as 26 days though many waste workers take no leave. The average wage for low-skilled workers is from www.tradingeconomics. com/india/wages while the minimum wage for 2015 is taken from www.delhi.gov.in/wps/wcm/ connect/doit_labour/Labour/Home/Minimum+Wages/

5. Informants: two millers and a mill engineer.

6. Informant: waste department worker.

7. Informants: health inspector, three female railway sanitation workers.

8. Informants: informal leader of wholesale market; two meals hotels owners, two stall-fed cattle rearers; four pigmen.

9. An army of domestic servants, which we could not study, is used for this work. The three Thotti ("scavenger" caste) women we met said they earn Rs3,000 per month plus food.

10. Informants: 11 MSWs.

11. Informants: local citizens plus one company supervisor (labourers have no mutual language in common).

12. Informants: four wholesalers.

13. Informants: 13 Irular waste-gatherers, four rough sleeping waste collectors.

14. Local property and professional tax were reported to us to raise only Rs $4 \mathrm{cr}$. The municipality therefore relies on party-politicised intra-state transfers.

15. Manual scavenging is the term for the removal by hand of human faeces from toilets (Human Rights Watch, 2014).

16. Some 10 per cent are from the Thotti (manual scavenging ) caste; of the 80 per cent about half are "Arundathiars" from AP - renamed and legitimated as scheduled tribe and Kattu Naickers; while
Indian urban waste economy 
about half are scheduled caste paraiyans. The remainder are downwardly mobile Naickers and Mudaliars - backward castes.

17. Irulars are tribal people, about 100,000 among Tamil Nadu's $70 \mathrm{~m}$ population, originally - and still - semi-nomadic ethno-medically skilled forest dwellers and snake-catchers, whose language has no script www.thehindu.com/news/cities/chennai/not-a-charmed-life-for-snake-catchers-atwork/article16004.ece; www.thehindu.com/todays-paper/tp-features/tp-metroplus/voices-fromthe-forest/article2657724.ece "They are perhaps the poorest and most miserable community in the district". www.frontline.in/static/html/f12826/stories/20111230282611700.htm and after multiple evictions and encroachments work in rice mills (with paddy still protected by its husk) and brick kilns, often as bonded labour and in waste.

18. Contrast this with the depiction of coercive and criminalised relations of destitution in HarrissWhite (2005).

19. Informants: 11 municipal workers.

20. Informants: the two company proprietors and their families.

21. Informants: one director of health and medical doctor at the state hospital, five "housekeepers" in state and private hospitals, one supervisor.

22. Informants: many drinkers, one lawyer and two state retail outlet employees.

23. Notation: $\mathrm{PHF}(\mathrm{M}) \mathrm{HK}=$ public hospital female (male) housekeeper; $\mathrm{Pv}=$ private.

24. A breakdown for one Tasmark (government) shop is 1,550 quarter bottles of brandy; 500 half bottles and 750 beer bottles. Demand for half bottles is on a rapid increase.

25. A "full bottle" is 750 millilitres. A quarter bottle is $190 \mathrm{ml}$. At 40 per cent proof this is 309 calories.

26. Liquor consumption also generates cardboard waste from cartons and plastic waste cups.

\section{References}

Basile, E. (2013), Capitalist Development in India's Informal Economy, Routledge, London.

Basile, E. and Harriss-White, B. (2010), "India's informal capitalism and its regulation”, International Review of Sociology, Vol. 20 No. 3, pp. 457-471.

Centre for Environment and Education (CEE) (2014), Sourcebook on Solid and Liquid Waste Management in Rural India, Centre for Environmental Education, New Delhi.

Chen, M.A. (2007), "Rethinking the informal economy: linkages with the formal economy and the formal regulatory environment”, Working Paper No. 46, DESA, United Nations Department of Economic and Social Affairs, New York, NY.

Coffey, D., Gupta, A., Hathi, P., Spears, D., Srivastav, N. and Vyas, S. (2015), "Culture and the health transition: understanding sanitation behaviour in rural north India", working paper, International Growth Centre, London School of Economics, London, available at: www.theigc.org/wp-content/uploads/2015/04/Coffey-et-al-2015-Working-Paper.pdf (accessed 30 March 2016).

Demaria, F. (2010), "Shipbreaking at Alang-Sosiya (India): an ecological distribution conflict", Ecological Economics, Vol. 70 No. 2, pp. 250-260.

Desai, S.B., Dubey, A., Joshi, B.L., Sen, M., Shariff, A. and Vanneman, R. (2010), Human Development in India Challenges for a Society in Transition, Oxford University Press, New Delhi.

Dinler, D. (2014), "Valuing waste: a multi-sited analysis of rules and regulations in the recycling market from Ankara to London", unpublished $\mathrm{PhD}$ thesis, School of Oriental and African Studies, London University, London.

Food and Agriculture Organisation (n.d.), Extent of Food Losses and Waste, FAO, Rome, available at: www.fao.org/docrep/014/mb060e/mb060e02.pdf (accessed 30 March 2016). 
Gill, K. (2009), Of Poverty and Plastic: Scavenging and Scrap Trading Entrepreneurs in India's Urban Informal Economy, Oxford University Press, New Delhi.

Gupta, A. (1995), "Blurred boundaries: the discourse of corruption, the culture of politics, and the imagined state", American Ethnologist, Vol. 22 No. 2, pp. 375-402.

Harriss-White, B. (2005), "Destitution and the poverty of its politics”, World Development, Vol. 33 No. 6, pp. 881-891.

Harriss-White, B. (2012), "Capitalism and the common man", Agrarian South: Journal of Political Economy, Vol. 1 No. 2, pp. 109-160.

Harriss-White, B. and Rodrigo, G. (forthcoming), "Discrimination in the waste economy: narratives from the waste-workers of a small town", Journal of Social Inclusion Studies.

Harriss-White, B., Olsen, W., Vera Sanso, P. and Suresh, V. (2013), "Multiple shocks and slum household economies in South India", Economy and Society, Vol. 42 No. 3, pp. 400-431.

Hodges, S. (2013), "Biotrash: the urban metabolism of medical garbage in India", paper presented at the Center for Historical Research, Ohio State University, Cleveland, OH, 5 April.

Hodges, S. (2015), "The Skin of the city: moral and material histories of plastic in India", paper presented to the Conference 'Burden of the Urban', Tata Institute for Social Sciences, Mumbai, December.

Hoornweg, D., Bhada-Tata, P. and Kennedy, C. (2013), "Waste production must peak this century", Nature, Vol. 502 No. 7473, pp. 615-617.

Human Rights Watch (2014), Cleaning Human Waste: "Manual Scavenging," Caste, and Discrimination in India, Human Rights Watch, New York, NY, available at: www.hrw.org/report/2014/08/25/cleaninghuman-waste/manual-scavenging-caste-and-discrimination-india (accessed 30 March 2016).

International Labour Office (2012), Statistical Update on Employment in the Informal Economy, International Labour Office, Department of Statistics, Geneva, available at: http://laborsta.ilo. org/applv8/data/INFORMAL_ECONOMY/2012-06-Statistical\%20update\%20-\%20v2.pdf (accessed 30 March 2016).

Jairaj, A. and Harriss-White, B. (2006), "Social structure, tax culture and the state: Tamil Nadu, India", Economic and Political Weekly, Vol. XLI No. 51, pp. 5247-5257.

Kannan, K.P. (2008), "Dualism, informality and social inequality: an informal economy perspective of the challenge of inclusive development in India”, Presidential Address, Indian Society of Labour Economics, Annual Conference, Lucknow, 13 December.

Kar, D. (2010), The Drivers and Dynamics of Illicit Financial Flows from India: 1948-2008, Ford Foundation/Global Financial Integrity, Center for International Policy, Washington, DC, available at: www.gfintegrity.org/wp-content/uploads/2014/02/GFI_India.pdf (accessed 30 March 2016).

Kim, Y. (2008), "The outside and inside meanings of alcohol: changing trends in Indian urban middle class drinking", DPhil thesis, Oxford University, Oxford, available at: www.southasia.ox.ac.uk/ sites/sias/files/documents/Oxford $\%$ 20University $\%$ 20CSASP $\% 20-\% 20$ Work $\% 20$ in $\% 20$ Progress \%20paper\%20Yoon \%20Hui\%20Kim.pdf (accessed 30 March 2016).

National Council for Enterprises in the Unorganised Sector (2008), "Contribution of the Unorganised sector to GDP Report of the Sub Committee of a NCEUS Task Force", Working Paper No. 2, NCEUS, New Delhi, available at: http://nceuis.nic.in/Final_Booklet_Working_Paper_2.pdf (accessed 30 March 2016).

Prakash, A. (2014), Dalit Capital: State, Markets and Civil Society in Urban India, Routledge, New Delhi.

Raj, S.N.R. and Sen, K. (2016), Out of the Shadows? The Informal Sector in Post-Reform India, Oxford University Press, New Delhi.

Ramesh, B.P. (2004), "Cyber Coolies' in BPO: insecurities and vulnerabilities of non-standard work", Economic and Political Weekly, Vol. 39 No. 5, pp. 492-497.

Standing, G. (2011), The Precariat: The New Dangerous Class, Bloomsbury, London. 
IJSSP

$37,7 / 8$

434

Stanley, J. (2015), "A future not so golden: liberalization, mechanization and conflict in arni's gold ornaments cluster", in Harriss-White, B. (Ed.), Middle India and Urban-Rural Development: Four Decades of Change, Chapter 5, Springer, Heidelberg and New Delhi, pp. 131-150.

Thorat, S., Tagade, N. and Naik, A.K. (2016), "Prejudice against reservation policies", Economic and Political Weekly, Vol. 51 No. 8, pp. 61-69.

White, R., Gathorne-Hardy, A., Harriss-White, B. and Hema, R. (2012), "Resources, greenhouse gas emissions, technology and work in production and distribution systems: materiality in Rice in India”, Working Paper No. 1, RGTW, Oxford, available at: www.southasia.ox.ac.uk/workingpapers-resources-greenhouse-gases-technology-and-jobs-indias-informal-economy-case-rice\# sthash.20ipmfhq.dpuf (accessed 30 March 2016).

\section{Corresponding author}

Barbara Harriss-White can be contacted at: barbara.harriss-white@qeh.ox.ac.uk

For instructions on how to order reprints of this article, please visit our website: 